\title{
APPLICATION OF ROTATED FILM APPARATUS AT PRODUCTION OF MULTI-COMPONENT FRUIT PASTS
}

\author{
Oleksandr Cherevko \\ Department of Processes, Devices and Automation of Food Production \\ Kharkiv State University of Food Technology and Trade \\ 333 Klochkivska str., Kharkiv, Ukraine, 61051 \\ Valeriy Mykhaylov \\ Department of Processes, Devices and Automation of Food Production \\ Kharkiv State University of Food Technology and Trade \\ 333 Klochkivska str., Kharkiv, Ukraine, 61051 \\ v.mykhailov@hduht.edu.ua \\ Aleksey Zagorulko \\ Department of Processes, Devices and Automation of Food Production \\ Kharkiv State University of Food Technology and Trade \\ 333 Klochkivska str., Kharkiv, Ukraine, 61051 \\ zagorulko@hduht.edu.ua \\ Andrii Zahorulko \\ Department of Processes, Devices and Automation of Food Production \\ Kharkiv State University of Food Technology and Trade \\ 333 Klochkivska str., Kharkiv, Ukraine, 61051 \\ zagorulkoAN@hduht.edu.ua
}

\begin{abstract}
The aim of the study is to probate the improved rotated film apparatus (RFA) at producing high-quality multi-component fruit pasts. The construction of the improved RFA with an innovative solution as to the system of heating its working chamber at the expanse of using a radiating heater - FFREhRT is developed. The designed construction is resource-effective and allows to concentrate fruit puree by using saving non-inertial thermal regimes $\left(50 \ldots 60{ }^{\circ} \mathrm{C}\right)$ with processing duration $0,65 \ldots 0,8$ min to content $25 \ldots 30 \%$ of RM. At the researches there was realized the probation of the improved RFA at concentrating offered multi-component fruit purees, based on apple, cranberry and haw.

The high quality of obtained multi-component fruit pasts was confirmed as a result of studying their structural-mechanical and color characteristics. Structural-mechanical parameters of studied fruit purees allowed to determine the influence of each component of the composition on the dispersed stability of an obtained structure of puree. It was established that the best disperse stable structure is inherent to the composition with percent content of apples, cranberries and haws as $60 \div 30 \div 10$ with the mean radius of microcapillaries $\overline{\mathrm{r}}=1,51 \mathrm{~nm}$.

As a result of concentrating fruit purees, there were determined their color characteristics by CIELab system. And the comparisons of the studied sample before and after concentration indicate their unessential change. Thus, for the recipe composition with best organoleptic indices: apple, cranberry, haw in ratio $60 \div 30 \div 10$, the brightness index for puree is: $\mathrm{T}=37,8 \%$, and for the concentrated past $-\mathrm{T}=36,4 \%$ respectively. All obtained compositions are characterized by the red-orange color that totally confirms preservation of their physical-chemical characteristics at thermal processing.

The improved RFA construction may be implemented at enterprises of tinned production for processing and getting high-quality fruit pasts for providing needs of food industry of the country.

Keywords: rotated film apparatus, fruit puree and pasts, structural-mechanical properties, color.
\end{abstract}

DOI: $10.21303 / 2461-4262.2018 .00599$

(C) Oleksandr Cherevko, Valeriy Mykhaylov, Aleksey Zagorulko, Andrii Zahorulko

\section{Introduction}

Everyday growth of the demand for natural food products conditions the necessity in implementing innovative solutions for their production [1]. It especially concerns the equipment and 
processing methods of natural fruit raw materials, because the existent technical equipment in most cases is characterized by certain defects, among which: metal-consumption, difficulties for maintenance, automation and other designing shortcomings [2]. And for providing artificial enrichment of multi-component mass with fruit raw materials with the essential content of biologically active substances (BAS) and acquiring treating-prophylactic properties by them, it is necessary to improve methods of its processing [3]. Just that is why, there is offered one of innovative solutions of existent constructive-technological tasks of tinned food industry of Ukraine.

The aim of the work is to conduct the probation study of the improved rotated film apparatus (RFA) at producing high-quality multi-component fruit pasts with offering the recipe ratio at mixing fruit raw materials that provides the artificial increase of BAS content and treating-prophylactic properties. And also the methods of determining the change of structural-mechanical features of obtained products depending on a mass share of each component and confirming conservation of quality characteristics of obtained products at the expanse of using methods of analyzing their color.

The offered innovative solutions allow to raise technical parameters of the equipment for concentrating natural raw materials using a suitable temperature regime and widening the assortment of high-quality multi-component fruit semi-products.

\section{Materials and Methods}

Experimental studies were conducted in the laboratories of Kharkiv state university of food and trade (Ukraine).

\section{1. Experimental device of the rotated film apparatus}

The studies of concentrating multi-component fruit puree were realized on the improved RFA that differs from a prototype by using a flexible film resisting electric heater of the radiating type (FFREhRT) [4]. The general look of the experimental device is presented on Fig. 1.

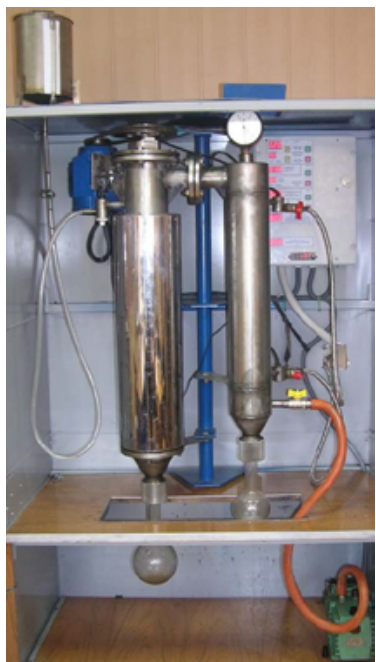

Fig. 1. Look of the improved experimental device RFA

The construction of the improved scheme of the experimental device RFA (Fig. 2) consists of the following elements: turning of the rotor drive is realized by electric motor 1 using wedgepass transmission 2. The number of rotor turns is determined by tachometer 3 . The product from chamber 4 is transmitted in the working chamber of RFA by pinion pump 5 .

The external surface of chamber with product 4 is enveloped by FFREhRT 7 of heating the output product. Chamber 4 contains blade mixer 8 for mixing puree-like mass. Regulation of the heating temperature and turning the speed of the mixer is realized by measuring block 9 with the insert electric motor and potentiometer CSP -2 . Regulation of product consumption is provided by bypass line with valves 10 . 
Consumption of the final product and condensate is measured by flow meter 11. Secondary steam is condensed in tube condenser 12. Vacuum in the apparatus is created by the vacuum-pump and controlled by vacuum-meter 13 .

The temperature of the apparatus wall, product in chamber 4, and temperature of the product on input and output of the working chamber are measured using chromel-copel thermocouples 14 , combined with the potentiometer CSP-2, fixed in measuring block 9.

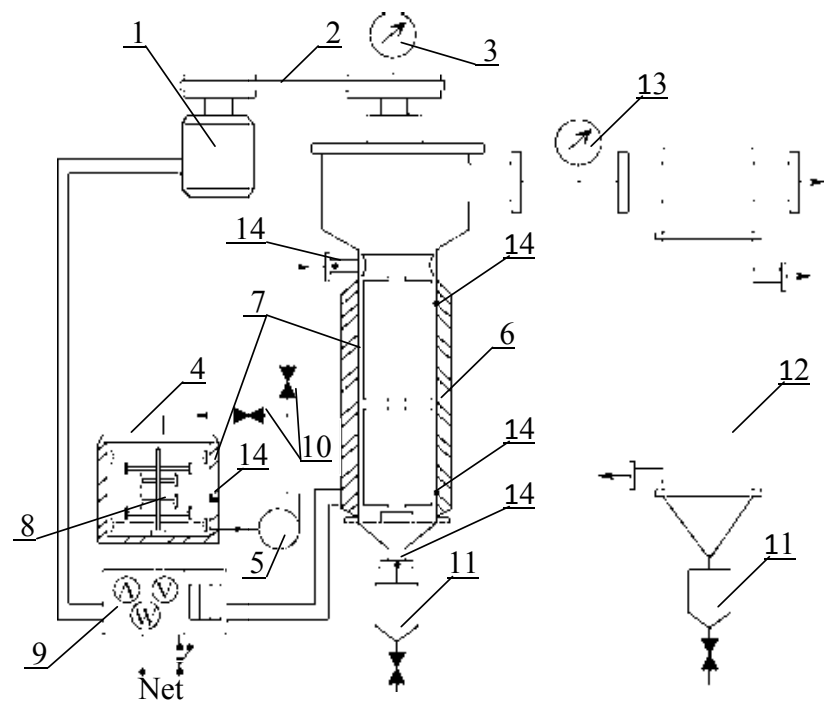

Fig. 2. The scheme of the experimental device for studying concentration processes that take place in RFA: 1 - electric motor; 2 - wedge-pass transmission; 3 - tachometer; 4 - chamber for the output; 5 - pinion pump; 6 - working chamber of RFA; 7 - flexible film resistant electric heater of radiating type (FFREhRT); 8 - blade mixer; 9 - measuring block C-50 with the fixed electric motor and potentiometer CSP -2; 10 - bypass line with valves;

11 - capacious consumer-meter; 12 - condenser; 13 - vacuum-meter; 14 - termocouples

The working surface of RFA is heated by FFREhRT, which external surface is enveloped by isolating material. The upper part of the apparatus body is spread and the separation space for the secondary thermocouple is created. The rotor with film-creating elements (blades) turns along the apparatus. The distribution ring that distributes the product that comes to the apparatus is fixed on the rotor shaft. The upper part of the cylinder contains a connecting pipe for conducting a product to the apparatus. The branch pipe for unloading a ready product is placed below the model [4].

For producing high-quality fruit semi-products taking into account their thermo-labile properties, there is offered to use the suitable temperature regime $\left(50 \ldots 60{ }^{\circ} \mathrm{C}\right)$ with the processing duration as $0,65 \ldots 0,8 \mathrm{~min}$ for the content $25 \ldots 30 \%$ of $\mathrm{RM}$. The offered perpetual apparatus is characterized by the low metal-consumption, transient thermal processing of a product and easy regulation. Just this fact provides maximal storage of food value of natural fruit raw materials.

2. 2. Materials, methods of studying compositions of multi-component fruit semi-products

At studying multi-component fruit semi-products, the main raw materials were chosen as apples (Antonyvka variety), cranberry (Hoves) and haw (Krymsky variety) (Fig. 3) with treating-prophylactic properties and also puree pasts on their base. Apples with the high content of a pectin substance that provides interaction with other components were used as the main share of multi-component semi-products. Wild cranberries have treating properties. Cranberries contain such important microelements as phosphorus, potassium, calcium, magnesium, iron, cobalt and iodine [5]. Berries contain vitamins $\mathrm{C}$ and $\mathrm{P}$, and also $\mathrm{B}_{1}$ and $\mathrm{B}_{2}$ [5]. They also contain much ursolic acid, which structure and genetics are familiar to many physiologically important hormones. They are used at catarrhal and infectious diseases, hypertonic ones and so on [5]. 
For preparing multi-component fruit semi-products, there is offered the recipe ratio of components (apple, cranberry, haw) in compositions:
a) $60 \div 30 \div 10$;
b) $65 \div 25 \div 10$;
c) $55 \div 40 \div 5$.

Haw fruits contain antioxidants, so they favor the blood circulation improvement, regulate heart muscle rates and help to clean vessels. Ursolic acid reveals cardio-stimulating action spread vessels. That is why berries are used at angina, hypertension, arrhythmia, neurosis and insomnia [5].

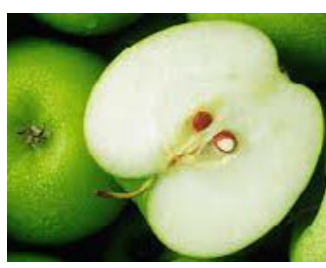

$a$

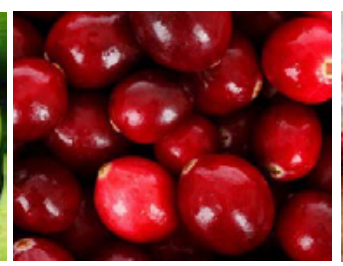

$b$

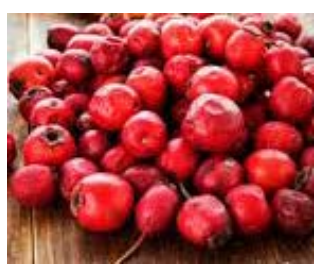

$c$

Fig. 3. Look of studied samples: $a$ - apple; $b$ - cranberry; $c$ - haw

The total acidity was determined by the standard titrometric method by SS 26188-84, mass share of dry substances - by SS 28561-90 [6, 7].

According to the offered recipe ratio of fruit components in multi-component composition, there were determined their influences on the formation of structural-mechanical properties (strength) in obtained food masses.

As a result of the experimental studies, it was established, that multi-component fruit mass changes previous structural-mechanical properties at the expanse of redistributing moisture by bound forms. For determining the influence of each multicomponent mass on forming the structural-mechanical properties in obtained food masses at changes of components ratio, there was used the dispersity of the product, namely the differential function of pores distribution by radiuses $\mathrm{f}(\mathrm{r})$, characterized by the mean radius of the porous structure of the product $\bar{r}$ [8].

$$
\overline{\mathrm{r}}=\int_{\mathrm{r} \min }^{\mathrm{r} \max } \mathrm{rf}(\mathrm{r}) \mathrm{dr}
$$

where $r_{\min }$ - minimal radius of microcapillaries; $r_{\max }$ - maximal radius of microcapillaries.

Tensometric method of Van-Bammelen was used for building sorption isotherms. Equation (2) was used for describing sorption-desorption isotherms [8]:

$$
\mathrm{u}=\mathrm{u}_{0} \exp \left(-\frac{\mathrm{a}_{293} \operatorname{In}(\mathrm{r})+\mathrm{b}_{293}}{\mathrm{r}}\right) \text {, }
$$

where $\mathrm{u}$ - relative humidity of the sample, rel.; $\mathrm{u}_{0}$ - hygroscopic humidity at sorption, rel., un.; $\mathrm{r}$ - current radius of capillaries, $\mathrm{nm} ; \alpha_{293} ; \mathrm{b}_{293}-$ stable, found regarding the look of experimental sorption-absorption isotherms at $\mathrm{T}=293 \mathrm{~K}$.

The distinctive feature of this methodology is the fact that constants a and $\mathrm{b}$, included in equation (2), at the same time are included in analytic expression (3) that describes DFS.

$$
f(r)=\frac{b_{293}-a_{293}+a_{293} \ln (r)}{r^{2}} \exp \left(-\frac{a_{293} \ln (r)+b_{293}}{r}\right) .
$$

It essentially facilitates DFS determination for combined masses and food products in whole. The use of equation (3) at the correspondent choice of values of the parameters a, b, $\mathrm{W}_{0}$ allows to find values of balanced humidities of sorption-desorption curves in the whole diapason 
of the relative humidity of air up to its hygroscopic value. For raising the exactness of the obtained values $a, b, W_{0}$ it is necessary to sort out values $(\varphi)$ and to average determined values of parameters of curve (1) [8].

The passage from the relative humidity of air $(\varphi)$ to radiuses of microcapillaries (r) is realized by formula (4):

$$
\mathrm{r}_{1}=\frac{2 \sigma \mathrm{V}}{\mathrm{RTIn} \phi}
$$

where $\sigma$ - surface tension of water; $\mathrm{V}$ - molar volume of water steam; $\mathrm{R}$ - gas constant.

Such approach allows to determine the parameters a and $\mathrm{b}$ (and $\mathrm{W}_{0}$ if necessary) easily by experimental points of sorption-absorption isotherms and to assess the dispersity of experimental samples by formulas (3), (5):

$$
\mathrm{Q}_{\phi}=\frac{\left(\mathrm{T}_{2} \mathrm{r}_{2}-\mathrm{T}_{1} \mathrm{r}_{1}\right) \mathrm{RT}_{1} \operatorname{In} \phi}{\left(\mathrm{T}_{2}-\mathrm{T}_{1}\right) \mathrm{r}_{1}},
$$

where $r_{1}$ - maximal radius of microcapillaries, filled at the expanse of sorption of water steam at the relative humidity of air $\varphi$ and temperature $T_{1}=293 \mathrm{~K}$, found by Tompson formula [8].

The obtained experimental data of balanced humidity for recipe compositions, presented in Table 1, allow to construct DFS isotherms.

\section{Table 1}

Experimental values of initial humidity of fruit compositions and calculating values of isotherm and DFS

\begin{tabular}{|c|c|c|c|c|}
\hline \multirow{2}{*}{ Constant isotherms } & \multicolumn{3}{|c|}{ Composition samples } & \multirow{2}{*}{ Control (apple puree) } \\
\hline & $\mathbf{a}$ & b & c & \\
\hline $\mathrm{W}_{0}$ & 0,35 & 0,34 & 10,2 & 0,65 \\
\hline $\mathrm{W}_{0,2}$ & 0,08 & 0,06 & 0,08 & 0,12 \\
\hline $\mathrm{W}_{0,4}$ & 0,12 & 0,10 & 0,15 & 0,14 \\
\hline $\mathrm{W}_{0,6}$ & 0,18 & 0,12 & 0,11 & 0,15 \\
\hline $\mathrm{W}_{0,9}$ & 0,30 & 0,28 & 0,18 & 0,35 \\
\hline$a_{313}$ & 0,40 & 0,46 & 0,06 & 1,4 \\
\hline $\mathbf{B}_{313}$ & 1,17 & 1,48 & 0,5 & 1,8 \\
\hline$\Theta_{0,5}$ & 2,82 & 2,8 & 6,3 & 1,05 \\
\hline$\Theta_{0,7}$ & 1,78 & 1,83 & 4,5 & - \\
\hline$\Theta_{0,9}$ & 1,52 & 0,7 & 1,7 & $\mathbf{0 , 1 0}$ \\
\hline$\sum \Theta$ & 6,2 & 5,6 & 12,6 & 1,16 \\
\hline
\end{tabular}
parameters

As a result of the analysis of obtained experimental data of multicomponent fruit masses and their mathematical processing according to the methodology, presented in work [8], there were calculated the results of average radiuses of microcapillaries of muticomponent natural compositions.

Color-creating parameters were determined by MCO method (International system of coordinates CIELab by the parameters L, a, b) [9]. The studies of diffuse reflection of samples were realized on the spectrophotometer SF-2000 (producer «SDB Spectrum», Russia) in the diapason $380 \ldots 700 \mathrm{~nm}$ with the step in $10 \mathrm{~nm}$ and number of accumulation cycles -20 . After that, color characteristics of the studied samples in CIELab system were determined using inset SFScan software [10]. 


\section{Results}

At determining changes structural-mechanical properties of multicomponent fruit masses, apple puree was used as a control. As a result of the studies as to pores distribution by radius (DFS) for offered recipe compositions, it was established, that the higher dispersity of samples, the more number of microcapillaries with less radius of pores. Just this fact results in forming the large contact surface between components of compositions and provides creation of combined products.

As a result of analyzing DFS, there was compared the influence of the mass share of cranberries on the dispersity of the obtained compositions of multicomponent fruit purees taking into account preliminary calculated values of mean radiuses of capillaries: $a-\bar{r}=1,51 \mathrm{mn}, b-$ $\overline{\mathrm{r}}=1,69 \mathrm{~nm}, \mathrm{c}-\overline{\mathrm{r}}=1,7 \mathrm{~nm}$. It may be stated, that at increasing the cranberry content from 25 to $30 \%$ (compositions $b$ and a) there is observed the increase of the dispersity of the studied puree.

At the experiment there were obtained and compared color-creating parameters in the international system of coordinates by CIELab system, brightness and color in the experimental multicomponent fruit compositions (puree, pasts). The obtained results were compared in Table 2.

Table 2

Comparison of color-creating parameters of experimental multicomponent fruit compositions by CIELab system

\begin{tabular}{|c|c|c|c|c|c|c|c|c|c|}
\hline \multirow{2}{*}{$\begin{array}{l}\text { Samples of compo- } \\
\text { sitions ratio }\end{array}$} & \multicolumn{4}{|c|}{ Puree } & \multicolumn{4}{|c|}{ Past } & \multirow{2}{*}{$\begin{array}{l}\text { Visual color of } \\
\text { fruit composition }\end{array}$} \\
\hline & $\mathbf{L}$ & $\mathbf{a}$ & $\mathbf{b}$ & $\begin{array}{c}\text { Brightness, } \\
\text { T, } \%\end{array}$ & $\mathbf{L}$ & $\mathbf{a}$ & $\mathbf{b}$ & $\begin{array}{c}\text { Bright- } \\
\text { ness, T, \% }\end{array}$ & \\
\hline a $(60 \div 30 \div 10)$ & 18 & 26 & 24 & 37,8 & 15 & 23 & 21 & 36,4 & Red-orange \\
\hline $\mathrm{b}(65 \div 25 \div 10)$ & 17 & 27 & 19 & 36,2 & 15 & 22 & 18 & 35,7 & Red-orange \\
\hline c $(55 \div 40 \div 5)$ & 16 & 25 & 22 & 35,2 & 14 & 21 & 19 & 34,5 & Red-orange \\
\hline
\end{tabular}

The analysis of the data of experimental samples of multicomponent fruit compositions (purees, pasts), presented in Table 2, confirms the minimal change of their physical-chemical properties, because at using the appropriate temperature regime the brightness of samples is saved by the inherent red-orange color. Taking it into account, it is possible to state the maximal conservation of BAS and treating-prophylactic properties in the final product - multicomponent pasts. It became possible at the expanse of using the improved RFA.

\section{Conclusions}

There was developed the construction of the rotor film apparatus with the innovative solution as to the system of heating its working chamber at the expanse of using the radiating heater - FFREhRT. It provides getting multicomponent fruit pasts of the high quality. Such construction is resource-effective and allows to concentrate fruit purees using saving non-inertial heat regimes $\left(50 \ldots 60{ }^{\circ} \mathrm{C}\right)$ with processing duration $0,65 \ldots 0,8 \mathrm{~min}$ for content $25 \ldots 30 \% \mathrm{RM}$. The studies probated the improved RFA at concentrating the offered multicomponent compositions of fruit purees, based on apples (Antonyvka variety), cranberries (Hoves variety) and haws (Krymsky variety).

The high quality of obtained multi-component fruit pasts was confirmed as a result of studying their structural-mechanical and color characteristics. Structural-mechanical parameters of studied fruit purees allowed to determine the influence of each component of the composition on the dispersed stability of the obtained structure of puree. It was established, that the best disperse stable structure is inherent to the composition with percent content of apples, cranberries and haws as $60 \div 30 \div 10$ with the mean radius of microcapillaries $\overline{\mathrm{r}}=1,51 \mathrm{~nm}$.

As a result of concentrating fruit purees, there were determined their color characteristics by CIELab system. The comparison of the studied samples before and after concentrating indicates their unessential change. Thus, for the recipe composition with best organoleptic parameters: apple, cranberry, haw in ratio $60 \div 30 \div 10$, the brightness parameter for puree is: $\mathrm{T}=37,8 \%$, and for concen- 
trated past $-\mathrm{T}=36,4 \%$ respectively. All obtained compositions are characterized by the red-orange color that totally confirms saving their physical-chemical properties at thermal processing.

The further development of the studies is planned to be directed on elaborating waste-free production of fruit pats and dried powders on its base. The improvement of the correspondent equipment for preliminary thermal processing of vegetable raw materials is aimed at decreasing resource consumption.

The improved construction of RFA may be implemented at enterprises of tinned food production for processing and obtaining high-quality fruit pasts. Fruit pasts may be recommended in food rations as an independent product and also for producing non-alcoholic and vodka drinks, confectionary and bakery products and other needs of food industry of the country.

\section{References}

[1] Shazzo, R. I., Ovcharova, G. P. (2005). Produkty detskogo pitaniya iz rastitel'nogo i myasnogo syr'ya infrakrasnoy sushki. Khranenie i pererabotka sel'khozsyr'ya, 1, 50-52.

[2] Magomedov, G. O., Magomedov, M. G., Zhuravlev, A. A., Lobosova, L. A. (2015). The development of plants for the production of concentrated pastes of fruit and vegetable raw materials. Proceedings of the Voronezh State University of Engineering Technologies, 3, 13-16.

[3] Magomedov, G. O., Magomedov, M. G., Astredinova, V. V., Litvinova A. A. (2012). Technology concentration of fruit and vegetables. Proceedings of the Voronezh State University of Engineering Technologies, 4, 86-89.

[4] Cherevko, A. I., Kiptelaia, L. V., Mihailov, V. M., Zagorulko, A. E. (2009). Progressivnye protsessy kontsentrirovaniia netraditsionnogo plooovoshchnogo syr'ia. Kharkiv: KhSUFTT, 241.

[5] Eitenmiller, R. R. (2002). Vitamin analysis for the health and food sciences.2 Ed. CRC Press, 675 .

[6] GOST 26188-84. Produkty pererabotki plodov i ovoshhey, konservy myasnye i myasorastitel'nye. Metod opredeleniya rN (s Izmeneniem N 1) (1985). Moscow: Izdatel'stvo standartov, 3.

[7] GOST 28561-90. Produkty pishhevye konservirovannye. Metody opredeleniya sukhikh veshhestv ili vlagi (Vzamen GOST 13340.3-77) (2011). Moscow: Izdatel'stvo Standartinform, 9.

[8] Cherevko, A. I., Kiptela, L. V., Zaharenko, V. A., Zagorulko, A. N. (2013). Pat. No. 83943 UA. Method of determining the strength of the multicomponent structure of plant pastes. MPK G01N 30/00, A23L 1/06/. No. u201302710; declareted: 04.03.2013; published: 10.10.2013, Bul. No. 19, 4.

[9] Mizhnarodna komisiia z osvitlenosti. Available at: https:/uk.wikipedia.org/wiki/Міжнародна_ комісія_з_освітленості

[10] Kiptela, L. V., Zagorulko, A. M., Zagorulko, O. Ye. et. al. (2017). Analiz isnuiuchykh sposobiv vyznachennia yakosti produktiv kharchuvannia za kolorom. Prohresyvni tekhnika ta tekhnolohii kharchovykh vyrobnytstv restorannoho hospodarstva i torhivli, 2 (26), 354-363. 